\title{
STATIC ANALYSIS \\ OF THE TUBULAR ELECTROMAGNETIC \\ LINEAR ACTUATOR WITH PERMANENTS MAGNETS
}

\author{
Krzysztof Just* ${ }^{*}$ Paweł Piskur** \\ * 1st Airlift Base (1BLTr), Żwirki i Wigury 1c, 00-909 Warsaw, Poland; email: justk5@op.pl \\ ** Polish Naval Academy, Faculty of Mechanical and Electrical Engineering, Śmidowicza 69 Str., 81-127 \\ Gdynia, Poland; e-mail: p.piskur@amw.gdynia.pl
}

\begin{abstract}
In this paper a results of a static analysis of the tubular linear electromagnetic actuator is presented. The linear actuator consist of two parts: a cylindrical unmovable coils surrounded by a soft ferromagnetic case, and a runner made from sequence of permanent magnet with a soft ferromagnetic gasket. In the first part of the paper the analytical method was performed for preliminary analysis. In the second part of the paper the more detailed analysis was depicted with using finite element method (FEM). The magnetic circuit shape and impact of selected dimensions on static characteristics is presented. Then the axial and radial electromagnetic force as a function of the runner dimensions were analysed.
\end{abstract}

Key words:

tubular electromagnetic linear actuator, permanent magnet linear actuator, computer simulation, finite element method.

\section{Research article}

(C) 2018 Krzysztof Just, Paweł Piskur This is an open access article licensed under the Creative Commons Attribution-NonCommercial-NoDerivatives 4.0 license (http://creativecommons.org/licenses/by-nc-nd/4.0/) 


\section{INTRODUCTION}

The linear electromagnetic actuators are commonly used in many mechatronic systems. The main advantages are the simple design structure, fast response for to the input signal and lack of any mechanical transmission from the rotation movement to the linear one. On the other hand there is a not enough mathematical description and design algorithm. This is due to the nonlinearity connected with nonlinear distribution of magnetic field in space and current dependency on the coil inductance as well. What is more, the inductance of the coil depends on the runner position and velocity as well. The linear mathematical model of electromagnetic actuator is sufficient in many considerations, but not if a more accurate calculations are needed.

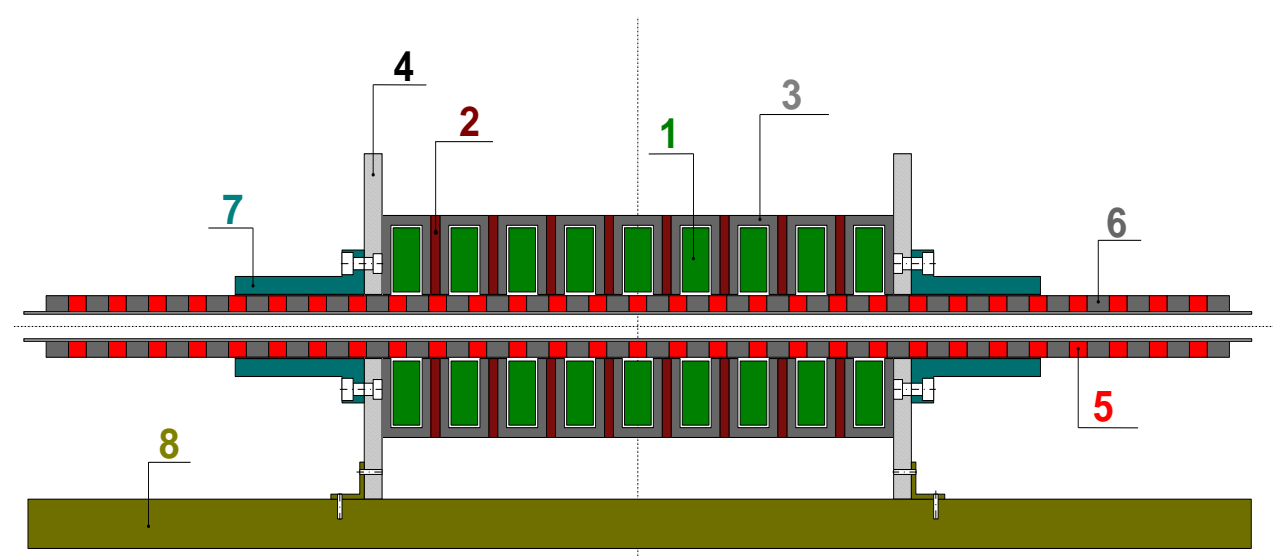

Fig. 1 . The scheme of the 9-coils electromagnetic linear actuator: $1-$ coil, $2-$ diamagnetic spacer, 3 - ferromagnetic case, 4 - holder, 5 - permanent magnet ring, 6 - ferromagnetic ring, 7 - linear bearing, 8 - fixed link

The scheme of the tubular linear actuator is presented in the fig. 1 . The electromagnetic actuator consist from coils and the runner with permanent magnet rings and soft ferromagnetic gaskets. The runner inertia will change proportionally to the mass of the core. The coils can be supplied with different algorithm. The coil magnetic field interacts with magnetic field from the runner permanent magnets. The length of the runner depends from the task the actuator is to being designed. In some application it is desired to design actuator with high static electromagnetic force able to keep position after disconnect the source power. Maintaining a stable position is realized by the both (stator and runner) magnetic fields interaction. 
In some application high static electromagnetic force is undesirable, when high speed of the runner and high energy efficiency is needed. That is why, in this paper both component of the electromagnetic forces were taken under consideration: the axial electromagnetic force and the radial one. What is more, the smoothness of the runner's movement depends on the relationship of the both forces.

In the first part of the paper an analytic analysis is performed. This kind of analysis is useful for the initial construction data. In the second part of the paper some detailed analysis is presented with using finite element method (FEM). In the paper [7] the analysis of the ferromagnetic case dimension impact on the actuator characteristics are presented. While in the paper [10] the impact of coils dimensions are analysed. In this paper the axial and radial components of the electromagnetic force is analysed as a function of the runner dimensions. Calculation were performed for discrete position of the magnetic runner.

Some assumption have been taken with eddy current and heating losses. It was assumed that their impact on the accuracy of the model is negligibly small.

\section{ANALYTICAL CALCULATIONS}

The analytical calculations were performed for variables described in the fig. 2 . To complete the dimensional data the rest of the dimensions are included in the tab. 1.

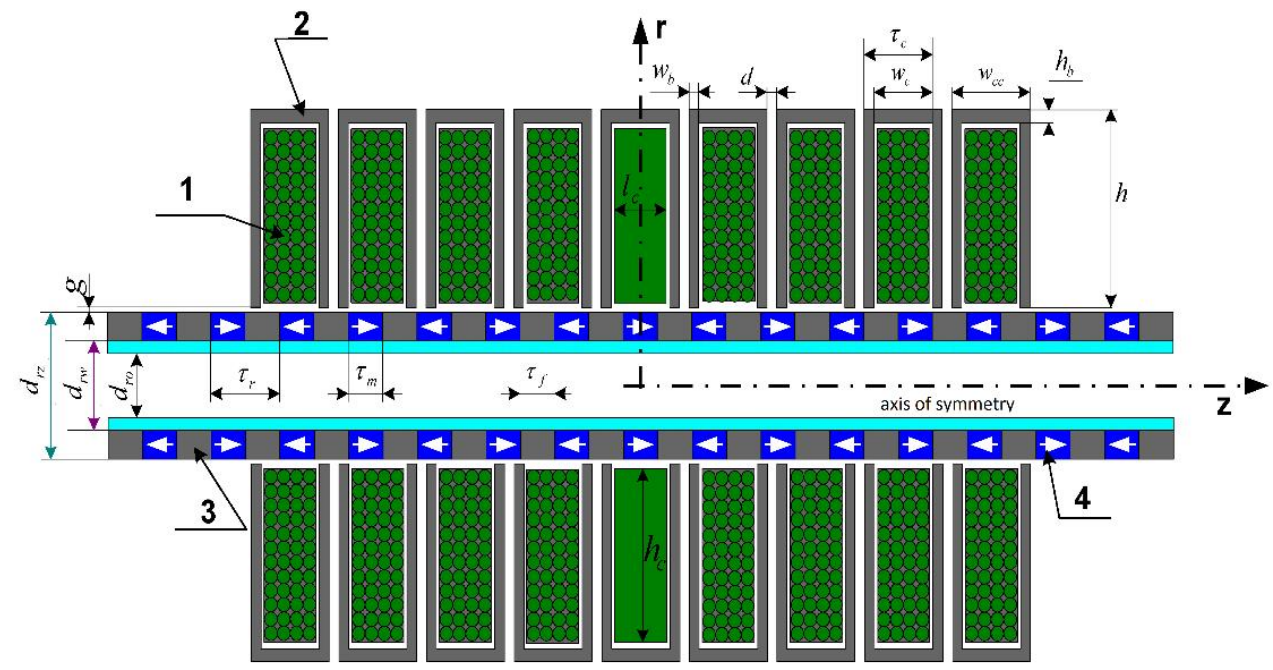

Fig. 2. The Axial section of the motor with dimensional designations:

1 - coil, 2 - ferromagnetic case, 3 - ferromagnetic ring, 4 - permanent magnet ring

$2(213) 2018$ 
Tab. 1. Actuator dimension descriptions

\begin{tabular}{|l|l|}
\hline \multicolumn{1}{|c|}{ Symbol } & \multicolumn{1}{c|}{ Description } \\
\hline$d_{r w}$ & inside diameter of the runner \\
\hline$d_{r z}$ & outer diameter of the runner \\
\hline$g$ & air gap between the runner and the stator \\
\hline$d$ & distance between coils \\
\hline$\tau_{m}$ & the length of the permanent magnet \\
\hline$\tau_{f}$ & the length of the ferromagnetic gasket \\
\hline$d_{c u}$ & diameter of the winding wire \\
\hline$l_{c}, h_{c}$ & the coil dimensions \\
\hline$h$ & the stator total dimension \\
\hline$h_{b}, w_{b}$ & the stator housing dimensions \\
\hline
\end{tabular}

The magnetic flux from permanent magnets flowing in the air gap can be calculated from equation:

$$
\psi_{m}=A_{m} \cdot B_{m}=A_{g} \cdot B_{g}
$$

where:

$A_{m}$ - surface area of the permanent magnet;

$A_{g} \quad$ - pole pieces surface area;

$B_{m}$ - magnetic flux density of the permanent magnets;

$B_{g} \quad$ - magnetic flus density in the air gap.

Due to the Maxwell law taking under consideration the continuity of magnetic flux, the relation between the permanent magnet diameter and the polar scale can be depicted [3]:

$$
B_{m} \cdot \frac{\pi}{4} \cdot\left(d_{r z}^{2}-d_{r w}^{2}\right)=\frac{1}{2} \cdot B_{g} \cdot \pi \cdot d_{g} \cdot \tau_{r}
$$

The magnetic flux density in the air gap can be calculated from the equation:

$$
2 H_{g} \cdot g+H_{m} \cdot l_{m}=0,
$$

where:

$H_{m}$ - magnetic field strength of permanent magnet;

$H_{g} \quad$ - magnetic field strength in the air gap.

Then the magnetic field strength in the air gap can be calculated from equation:

$$
H_{g}=-\frac{l_{m}}{2 \cdot g} \cdot H_{m} .
$$


Magnetic flux density in the air gap can be calculated:

$$
B_{g}=-\frac{\mu_{0} \cdot l_{m}}{2 \cdot g} \cdot H_{m} .
$$

Taking under consideration relations (5) and (1) the magnetic flux density of the permanent magnets can be defined as:

$$
B_{m}=-\frac{\mu_{0} \cdot l_{m} \cdot A_{g}}{2 \cdot A_{m} \cdot g} \cdot H_{m}
$$

This value can be achieved from magnetization curve:

$$
B_{m}=\mu_{r} \cdot H_{m}+B_{r}
$$

where:

$B_{r}$ - remanence induction;

$\mu_{r}$ - magnetic permeability coefficient of the magnet.

From the equations (6) and (7) the relation for magnetic flux density for permanent magnet can be presented as:

$$
B_{m}=\frac{\mu_{0} \cdot l_{m} \cdot A_{g} \cdot B_{r}}{2 \cdot \mu_{0} \cdot \mu_{m} \cdot A_{m} \cdot g+\mu_{0} \cdot A_{g} \cdot l_{m}} .
$$

From the equation (8) the magnetic flux from the permanent magnet can be written as:

$$
\psi_{m}=B_{m} \cdot A_{m}=\frac{\mu_{0} \cdot A_{g} \cdot A_{m} \cdot l_{m} \cdot B_{r}}{2 \cdot \mu_{0} \cdot \mu_{m} \cdot A_{m} \cdot g+\mu_{0} \cdot A_{g} \cdot l_{m}} .
$$

The radial section areas of the stator teeth and pole in the air gap can be determined from the equation:

$$
\begin{aligned}
& A_{z}=\pi \cdot\left(d_{g}+g\right) \cdot w_{z} \\
& A_{b}=\pi \cdot\left(d_{g}+g+2 \cdot h_{z}\right) \cdot w_{b}
\end{aligned}
$$

The dimension of the ferromagnetic coil housing can be expressed [5]:

$$
h_{f}=\frac{A_{b}}{\pi \cdot\left(d_{r z}+2 \cdot h_{t}+2 \cdot g+2 \cdot h_{c}+h_{b}\right)} .
$$

And the radial dimension of the coil can be calculated:

$$
h_{c}=\frac{1}{2} \cdot\left(D_{s z}-\left(d_{r z}+2 \cdot h_{t}\right)-2 \cdot g-2 \cdot h_{b}\right) \text {. }
$$

2 (213) 2018 
The preliminary parameters of magnetic circuit were taken from analytical calculation and from literature $[1,8]$. The assumption needed when model is considered as a discrete in space with linear dependencies. This is sufficient for preliminary analysis but not if more accurate model is needed. In the paper [4] there was shown that the dimension of the ferromagnetic case should be from 4 to $8 \mathrm{~mm}$. The movement is more smoothly if permanent magnets length $\tau_{m}$ to the runner circuit length $\tau_{r}$ ratio is from 0.45 to $0.65[1,9]$. All the dimension achieved from literature and from analytical analysis are presented in the tab. 2 .

Tab. 2. Initial dimensions and parameters of the actuator model adopted for consideration

\begin{tabular}{|c|c|c|}
\hline Symbol & Value & [unit] \\
\hline$d_{r w}$ & 12 & {$[\mathrm{~mm}]$} \\
\hline$d_{r z}$ & 24 & {$[\mathrm{~mm}]$} \\
\hline$g$ & 1 & {$[\mathrm{~mm}]$} \\
\hline$d$ & 4 & {$[\mathrm{~mm}]$} \\
\hline$\tau_{m}$ & 8 & {$[\mathrm{~mm}]$} \\
\hline$B r$ & 1.23 & {$[\mathrm{~T}]$} \\
\hline$\tau_{f}$ & 10 & {$[\mathrm{~mm}]$} \\
\hline$\tau_{r}$ & 18 & {$[\mathrm{~mm}]$} \\
\hline$d_{c u}$ & 0.85 & {$[\mathrm{~mm}]$} \\
\hline$N$ & 300 & {$[-]$} \\
\hline$l_{c}$ & 12 & {$[\mathrm{~mm}]$} \\
\hline$h_{c}$ & 24 & {$[\mathrm{~mm}]$} \\
\hline$h$ & 30 & {$[\mathrm{~mm}]$} \\
\hline$w_{c}$ & 14 & {$[\mathrm{~mm}]$} \\
\hline$W_{c c}$ & 22 & {$[\mathrm{~mm}]$} \\
\hline$w_{z}$ & 6 & {$[\mathrm{~mm}]$} \\
\hline$h_{z}$ & 1 & {$[\mathrm{~mm}]$} \\
\hline$w_{b}$ & 4 & [mm] \\
\hline$h_{b}$ & 4 & {$[\mathrm{~mm}]$} \\
\hline$D_{c z}$ & 86 & {$[\mathrm{~mm}]$} \\
\hline
\end{tabular}

\section{SIMULATION MODEL WITH FEM}

Two-dimensional, axisymmetric model of the actuator was designed for calculations and simulation tests (fig. 2) using an environment based on the finite element 
method. In the constructed models, the non-linearity of the magnetic field was modelled, while the influence of eddy currents and thermal losses in the magnetic field was omitted [6]. The model was created in the few steps presented in the fig. 3. Firstly, the geometry was created in the CAD package [2]. Then imported geometry to the FEM package was divided by the net of the nodes and the boundary and initial conditions were implemented. As a result of simulation the distribution of magnetic field is presented as well as the total magnetic force with the radial and axial components. Having done the simulation model, the basic optimization process was performed. The complete review method was choose for optimization process. The runner's permanent magnets dimensions were choose as a decision variables, while the optimization criteria was minimal the axial electromagnetic force to the radial electromagnetic force ratio.

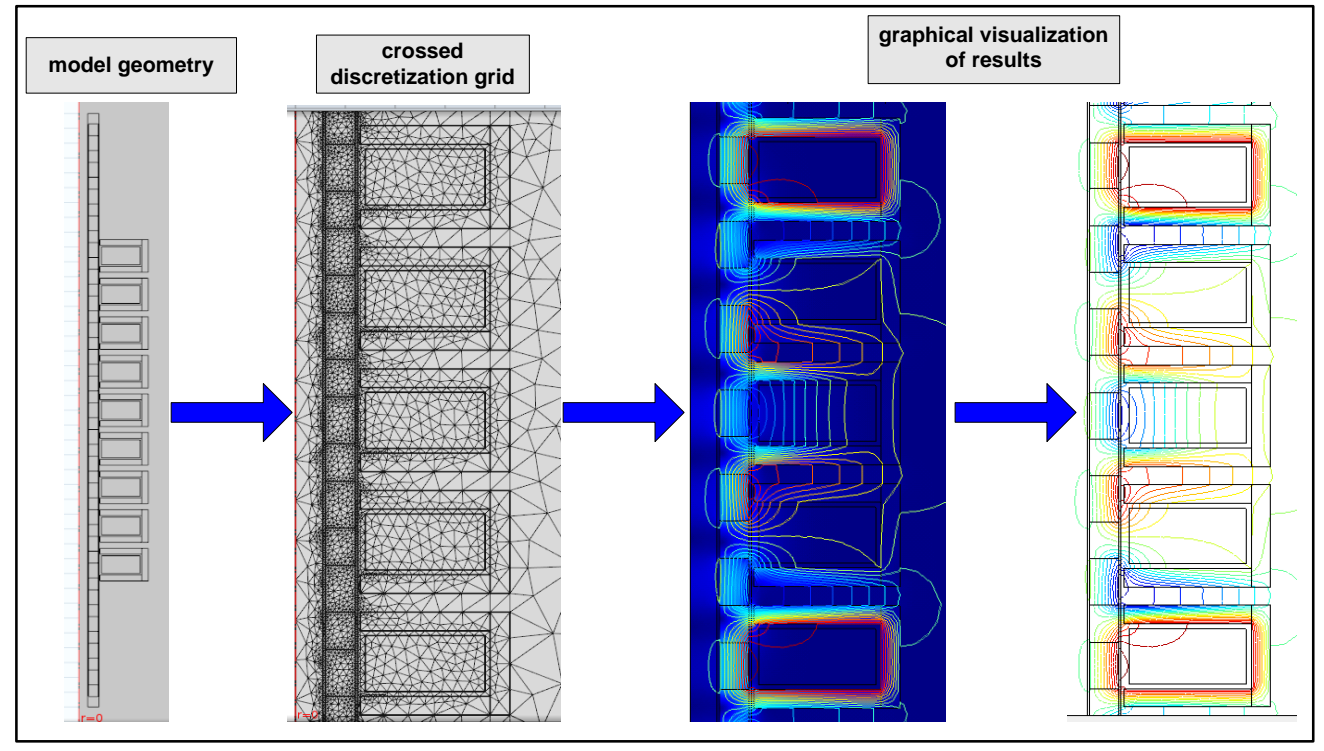

Fig. 3. Steps in the linear actuator magnetic field calculation

\section{RESULTS OF SIMULATION}

The volume of permanent magnets strongly affects the properties of the actuator, because it is closely related to the energy of the magnetic field. In the work, an analysis was made to determine the impact of dimensions of permanent magnets 
(thickness and width) on the average and maximum value of both the radial force presented as F1 in the fig. 4 (derived from permanent magnets) and axial force presented as F2 in the fig. 4 (when powering the windings). The following stator dimensions were adopted for the calculations (obtained from a separate analysis): height of coils $h_{c}=30 \mathrm{~mm}$, the width of the coils $l_{c}=12 \mathrm{~mm}$, thickness of the housing $h_{j}=4 \mathrm{~mm}$.

The thickness of permanent magnets was changed in the range from 1 to $11.5 \mathrm{~mm}$, with $0.5 \mathrm{~mm}$ increments, while maintaining a constant external radius $(12 \mathrm{~mm})$. The magnetic runner with thin walls $(1 \mathrm{~mm})$ is characterized by a negligible value of axial electromagnetic force (1.9 N). Unfortunately, at the same time its thrust is more than 3 times lower $(30 \mathrm{~N})$ than the force generated in the base model of the motor (fig. 5 and 6). Increasing the thickness of permanent magnets to $11.5 \mathrm{~mm}$ results in a significant increase in the axial component of the magnetic force. The largest increase in energy was observed when the thickness of the magnets changed to $6 \mathrm{~mm}$, further increase of thickness only slightly affects the increase of energy, but increases the weight of the runner.

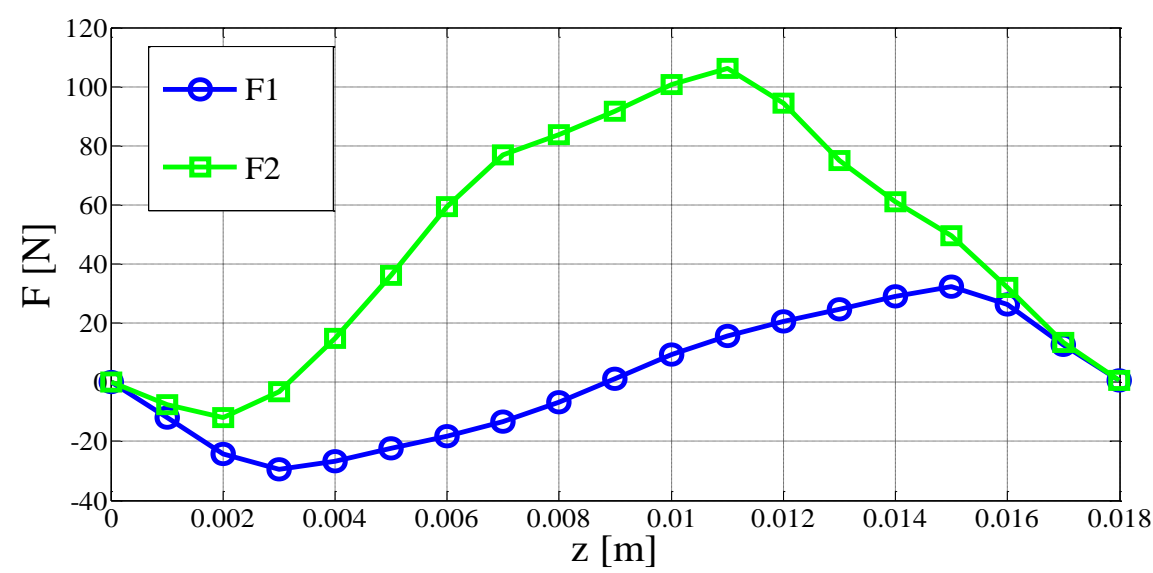

Fig. 4. Electromagnetic force (F1 - axial component, F2 - radial component) as a function of runner displacement

The largest increases in both forces occur in the range of the thickness of magnets from 4 to $6 \mathrm{~mm}$. The greater the thickness of the magnets, the more energy absorbs the thrust and the thrust increases the radial component force increases as well as the weight of the runner, which is undesirable. 


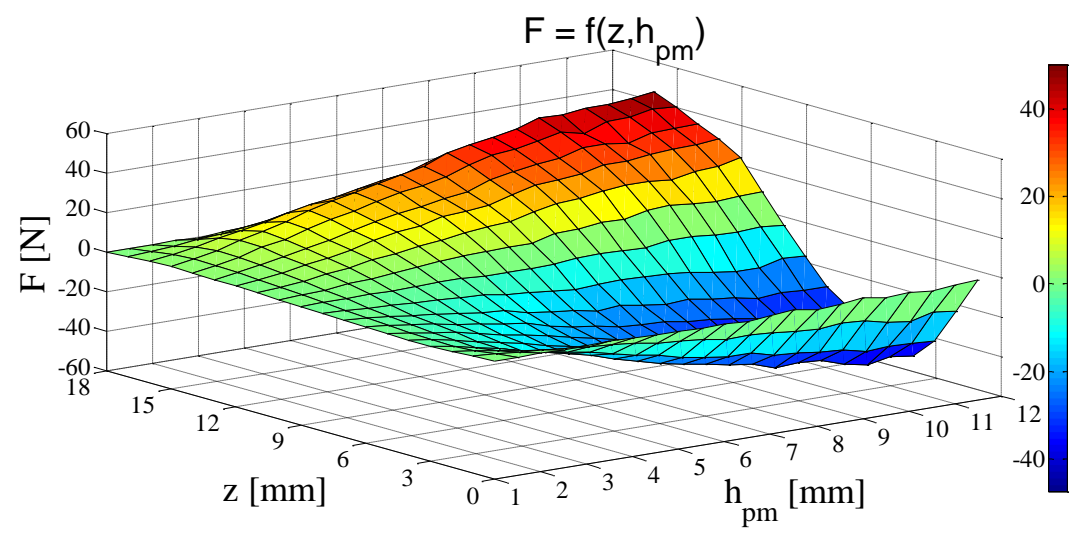

Fig. 5. Radial electromagnetic force as a function of runner displacement $(z)$ and as a function of the runner radial dimension $h_{p m}$

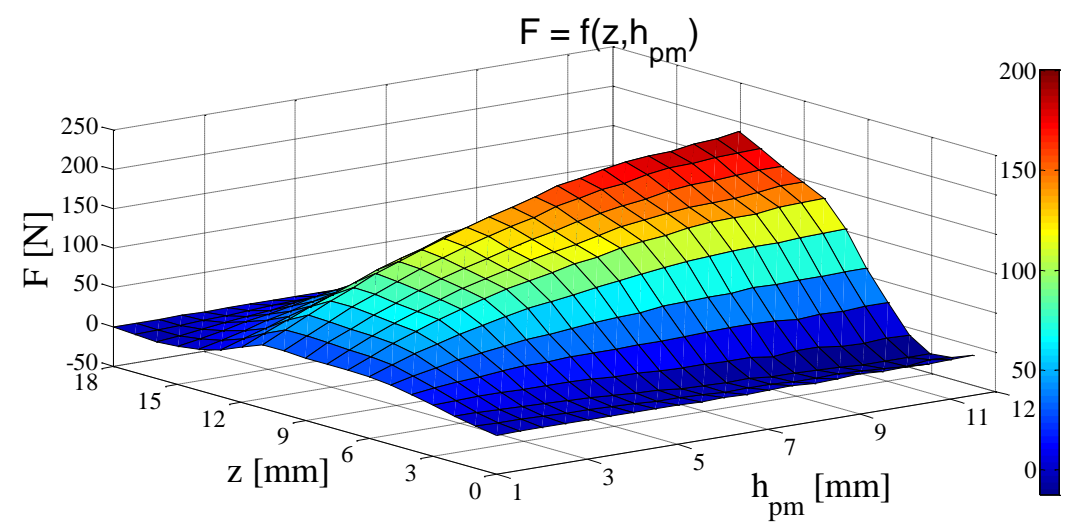

Fig. 6. Axial electromagnetic force as a function of runner displacement $(z)$ and as a function of the runner radial dimension $h_{p m}$

The design of permanent magnets aims to maximize axial component of the electromagnetic force and minimalize the radial component of the electromagnetic force. To estimate this condition, an indicator $k$ was introduced in the calculations determining the measure of the both electromagnetic force components ratio:

$$
k=\frac{F_{z \max }}{F_{\text {emax }}} \cdot 100 \%,
$$

where:

$F_{z \max }-$ maximal value of the radial component of the electromagnetic force;

$F_{e \max }-$ maximal value of the axial component of the electromagnetic force. 
Tab. 3 presents a comparison of the results of calculations of the electromagnetic forces achieve from analytical calculation and after optimization process of the permanent magnets runner.

Tab. 3. The results of force calculations for the modification of the magnetic circuit (the thickness and width of the permanent magnets changes)

\begin{tabular}{|c|c|c|c|c|c|c|c|c|}
\hline & $\begin{array}{c}\text { thickness } \\
{[\mathbf{m m}]}\end{array}$ & $\boldsymbol{F}_{\text {zmax }}[\mathbf{N}]$ & $\boldsymbol{F}_{\text {zavg }}[\mathbf{N}]$ & $\boldsymbol{F}_{\text {zmin }}[\mathbf{N}]$ & $\boldsymbol{F}_{\max }[\mathbf{N}]$ & $\boldsymbol{F}_{\min }[\mathbf{N}]$ & $\boldsymbol{F}_{\text {avg }}[\mathbf{N}]$ & $\boldsymbol{k}[\%]$ \\
\hline $\begin{array}{c}\text { Preliminary } \\
\text { values }\end{array}$ & 6 & 32,30 & 1,01 & $-29,58$ & 106,21 & $-12,01$ & 45,98 & 30,42 \\
\hline $\begin{array}{c}\text { Optimized } \\
\text { values }\end{array}$ & 5,5 & 29,28 & $-0,11$ & $-29,73$ & 145,55 & $-4,09$ & 64,59 & 20,12 \\
\hline Changes [\%] & $-8,33$ & $-9,30$ & $-88,90$ & $+0,50$ & $+37,05$ & $-65,97$ & $+40,46$ & $-10,20$ \\
\hline & $\begin{array}{c}\text { width } \\
{[\mathbf{m m}]}\end{array}$ & $\boldsymbol{F}_{\text {zmax }}[\mathbf{N}]$ & $\boldsymbol{F}_{\text {zavg }}[\mathbf{N}]$ & $\boldsymbol{F}_{\text {zmin }}[\mathbf{N}]$ & $\boldsymbol{F}_{\max }[\mathbf{N}]$ & $\boldsymbol{F}_{\min }[\mathbf{N}]$ & $\boldsymbol{F}_{\text {avg }}[\mathbf{N}]$ & $\boldsymbol{k}[\%]$ \\
\hline $\begin{array}{c}\text { Preliminary } \\
\text { values }\end{array}$ & 9 & 32,30 & 1,01 & $-29,58$ & 106,21 & $-12,01$ & 45,98 & 30,42 \\
\hline $\begin{array}{c}\text { Optimized } \\
\text { values }\end{array}$ & 5 & 17,53 & 6,43 & 0,53 & 170,48 & $-0,29$ & 56,65 & 10,29 \\
\hline Changes [\%] & $-44,4$ & $-45,73$ & $+539,29$ & $+98,22$ & $+60,51$ & $+97,58$ & $+23,18$ & $-66,17$ \\
\hline
\end{tabular}

The width of permanent magnets was changed in the range from 2 to $16 \mathrm{~mm}$, while maintaining a constant distance between the centres of permanent magnets.

The use of narrow magnets is characterized by the presence of a small radial electromagnetic force. As the width of the magnets increases, the axial component of the force increases, but over the width of $12 \mathrm{~mm}$ the changes decreases (fig. 7). The thrust force changes due to simultaneous changes in the width of the elements of the runner. Its value reaches the maximum for the width of 4-6 $\mathrm{mm}$, and then decreases with the change of dimension. The greatest changes in the ratio of both forces occur for width $6-14 \mathrm{~mm}$, the maximum value is reached for the widest magnets.

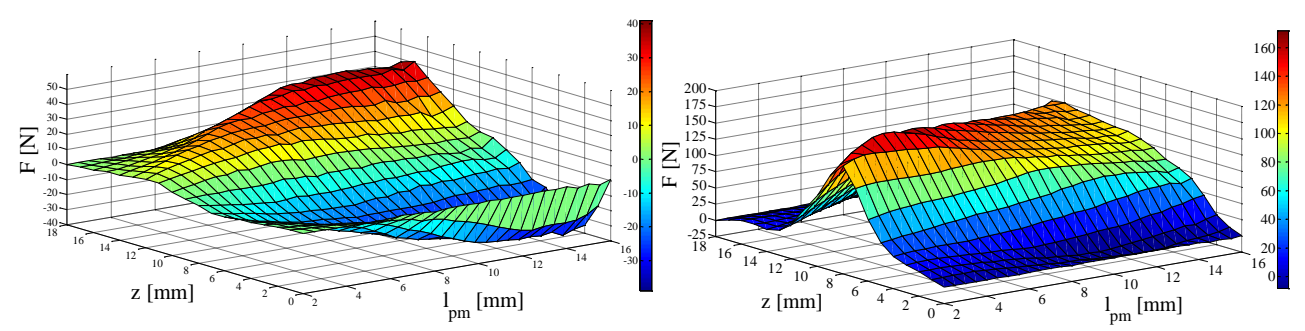

Fig. 7. Radial electromagnetic force (left) and axial electromagnetic force (right) as a function of runner displacement $(z)$ and as a function of the runner axial dimension $l_{p m}$ 

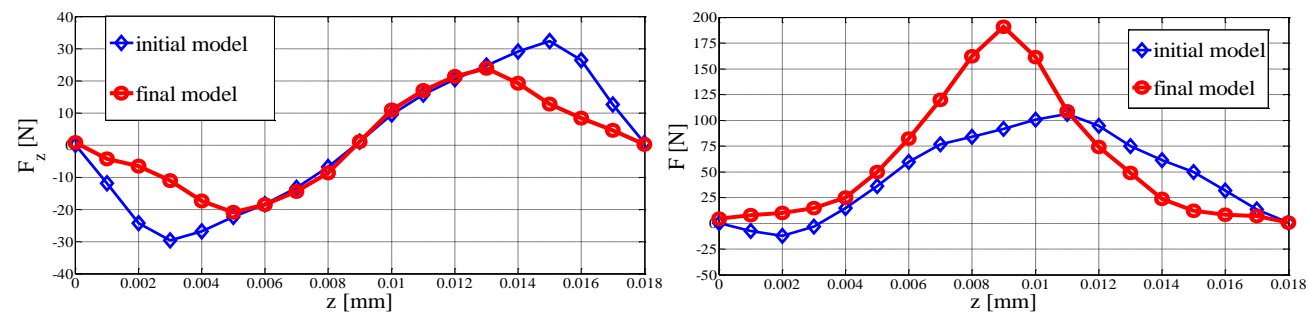

Fig. 8. Cogging and electromagnetic force as a function of runner displacement

The obtained results of the calculations allow to conclude that the increase in the width of the elements of the runner affects the increase of force only to a certain value, beyond which the force begins to decrease significantly.

The analysis showed it is difficult to determine the optimal values of the dimensions of the runner, it is only possible to estimate their range of variation, which is in the range of 4-8 $\mathrm{mm}$ for thickness and 3-9 $\mathrm{mm}$ for the widths of magnets.

\section{CONCLUSIONS}

The paper presents an analytical model for basic parameters and main dimensions calculations of the linear stepper motor with permanent magnets. The analytical model was used as an initial model for calculation the effect of dimension changes in the magnetic circuit of the runner on static characteristics made in the FEM environment (field model). The static characteristics as a function of geometric dimensions changes of the runner magnetic circuit of the linear stepper actuator with permanent magnets is presented.

Conducted multi-variant analysis of the impact of geometric dimensions of the runner on the static characteristics allowed to investigate which dimensions have the greatest impact on the electromagnetic force components. Increasing the thickness of permanent magnets causes a significant increase in the thrust force, but at the same time the value of the cogging coefficient and the mass of the runner increases. The large mass increases the inertia of the system, which is disadvantageous. Looking for the optimal solution, i.e. obtaining a high axial component of the electromagnetic force with the smallest weight of the runner elements, the range of the thickness of magnets from 4 to $6 \mathrm{~mm}$ was taken for further calculations. The simultaneous change of the permanent magnets and ferromagnetic inserts width have great impact on the value of the cogging coefficient and the axial component of the electromagnetic force. 
The analysis provided to the simulation model with better parameters compared to the initial model from analytical calculations (fig. 8). It has a greater thrust force, while reducing the cogging coefficient, which is advantageous from the point of view of the correct operation of the drive.

\section{REFERENCES}

[1] Bogusz P., Korkosz M., Prokop J., Analiza wpływu szerokości biegunów stojana i zębów wirnika na parametry eksploatacyjne silników reluktancyjnych przełączalnych na bazie obliczeń polowych, 'Zeszyty Problemowe. Maszyny Elektryczne', 2006, No. 75, pp. 201-206 [Analysis of the influence of stator poles and rotor teeth on the operational parameters of switched reluctance motors based on field calculations - available in Polish].

[2] COMSOL Multiphysics: AC/DC Module User's Guide.

[3] Gosiewski Z., Falkowski K., Zokowski M., Introductory Analysis of the Bearingless Induction Motor, 'Solid State Phenomena', 2009, Vol. 147-149, pp. 143-148, Main Theme: Mechatronic Systems and Materials III, DOI: 10.4028/www.scientific.net/SSP.147-149.143.

[4] Gosiewski Z., Kondratiuk M., Selection of Coils Parameters in Magnetic Launchers, 'Solid State Phenomena', 2009, Vol. 147-149, pp. 438-443, Main Theme: Mechatronic Systems and Materials III.

[5] Just K., Metodyka projektowania konstrukcji i sterowania mechatronicznego urzq̨dzenia wykonawczego ruchu liniowego, PhD thesis, Politechnika Koszalińska, Koszalin 2018 [Methodology of the designing the structure and control system of the linear mechatronic device - available in Polish].

[6] Just K., Tarnowski W., Model polowy zjawisk elektromechanicznych napędu liniowego z magnesami trwałymi, 'Biuletyn Wojskowej Akademii Technicznej, 2017, Vol. 66, No. 3, pp. 125-131 [The field model of electromechanical phenomena of linear drive with permanent magnets available in Polish].

[7] Piskur P., Tarnowski W., Just K., Model of the Electromagnetic Linear Actuator for Optimization Purposes, 23rd European Conference on Modelling and Simulation Projects, June 2009, DOI: $10.7148 / 2009-0708-0713$.

[8] Ristic-Djurovic J. L., Gajic S. S., Ilic A. Z. et al., Design and Optimization of Electromagnets for Biomedical Experiments With Static Magnetic and ELF Electromagnetic Fields, 'IEEE Transactions On Industrial Electronics', 2018, Vol. 65, Issue 6, pp. 4991-5000.

[9] Tomczuk B., Waindok A., Wizualizacja wyników obliczeń polowych przyjaznych środowisku siłowników elektromagnetycznych, 'Chemia. Dydaktyka. Ekologia. Metrologia', 2005, Vol. 10, No. 1-2 [Visualization of field calculation results of environmentally friendly electromagnetic actuators - available in Polish].

[10] Tomczuk B., Waindok A., Wpływ wymiarów uzwojenia stojana na siłę ciagu silnika tubowego $z$ magnesami trwałymi, 'Prace Instytutu Elektrotechniki', 2007, Vol. 231, pp. 163-172 [Influence of Dimensions of the Stator Winding on the thrust force of the tubular motor with permanent magnets - available in Polish]. 


\section{ANALIZA STATYCZNA ELEKTROMAGNETYCZNEGO TUBOWEGO SILNIKA LINIOWEGO Z MAGNESAMI TRWAŁYMI}

\section{STRESZCZENIE}

$\mathrm{W}$ artykule przedstawiono obliczenia obwodu magnetycznego napędu liniowego z magnesami trwałymi z zastosowaniem dwóch metod. Pierwsza metoda przedstawia analityczny sposób wyznaczania podstawowych wartości obwodu magnetycznego. W drugiej wykorzystano metodę elementów skończonych do wyznaczania wpływu wymiarów geometrycznych biegnika na charakterystyki statyczne napędu liniowego. Szczególną uwagę zwrócono na składowe osiowe i promieniowe siły elektromagnetycznej, których wzajemna relacja wpływa na płynność ruchu biegnika. Przedstawiony model silnika liniowego może zostać wykorzystany do optymalizacji zarówno konstrukcji, jak i sterowania.

\section{Słowa kluczowe:}

napęd elektromagnetyczny, liniowy silnik tubowy z magnesami trwałymi, metoda elementów skończonych, optymalizacja konstrukcji.

Article history

Received: 13.04.2018

Reviewed: 17.05.2018

Revised: $\quad 21.06 .2018$

Accepted: 22.06.2018 